\title{
Forest reserves and riparian corridors help maintain orchid bee (Hymenoptera: Euglossini) communities in oil palm plantations in Brazil
}

\author{
Thaline F. Brito ${ }^{1}$, Colin C. Phifer ${ }^{2}$, Jessie L. Knowlton ${ }^{2}$, Cynthia M. Fiser $^{2}$, \\ Nia M. Becker ${ }^{2}$, Fernanda C. Barros ${ }^{1}$, Felipe A. L. Contrera ${ }^{3}$, Márcia M. Maués ${ }^{4}$, \\ Leandro Juen ${ }^{5}$, Luciano F. A. MontaG ${ }^{5}$, Christopher R. Webster ${ }^{2}$, \\ David J. Flaspohler ${ }^{2}$, Marcos P. D. Santos ${ }^{6}$, Daniel P. Silva ${ }^{7}$

\footnotetext{
${ }^{1}$ Programa de Pós-Graduação em Zoologia, Universidade Federal do Pará/Museu Paraense Emílio Goeldi, Belém, Pará, Brazil

${ }^{2}$ School of Forest Resources and Environmental Science, Michigan Technological University, Houghton, MI, USA

${ }^{3}$ Laboratório de Biologia e Ecologia de Abelhas, Instituto de Ciências Biológicas, Universidade Federal do Pará, Belém, Pará, Brazil

${ }^{4}$ Laboratório de Entomologia, Embrapa Amazônia Oriental, Belém, Pará, Brazil

${ }^{5}$ Laboratório de Ecologia e Conservação, Instituto de Ciências Biológicas, Universidade Federal do Pará, Belém, Pará, Brazil

${ }^{6}$ Laboratório de Ecologia e Zoologia de Vertebrados - Ornitologia, Instituto de Ciências Biológicas, Universidade Federal do Pará, Belém, Pará, Brazil

${ }^{7}$ Departamento de Ciências Biológicas, Instituto Federal Goiano, Urutaí, Goiás, Brazil
}

Received 5 September 2016 - Revised 9 January 2017 - Accepted 24 January 2017

\begin{abstract}
Orchid bees (Apidae, Euglossini) are important pollinators in the Amazon forest. In eastern Brazilian Amazon, secondary forest and pastures are being replaced by oil palm plantations. Here, we tested the role of forest reserves and riparian corridors in maintaining orchid bees. We sampled bees in three different soil-type uses, comparing richness, abundance, and assemblage composition. Estimated richness was lowest in palm plantations than in forest reserves and riparian corridors on diversity of orchid bees. Riparian corridors had the highest abundance, followed by reserves, and oil palm plantations. Bee assemblage also varied with land cover, with the reserves having the most distinct composition. We also identified indicator bees for primary forest. Our results demonstrate riparian corridors and forest reserves can maintain orchid bees in oil palm landscapes.
\end{abstract}

\section{Amazon / Euglossini / fragmentation / land use / permanent protection areas}

\section{INTRODUCTION}

One of the greatest challenges facing conservation biologists in an age of rapid agricultural

Electronic supplementary material The online version of this article (doi:10.1007/s13592-017-0500-z) contains supplementary material, which is available to authorized users.

Corresponding author: T. Brito,

thalinebrito@gmail.com

Manuscript Editor: Klaus Hartfelder expansion for food, fiber, and fuel is understanding how to retain biodiversity and associated ecosystem services within sustainable production landscapes (MEA 2005; Tomich et al. 2011; Laurance et al. 2014). Pollination is a critical biodiversity-dependent ecosystem service in both natural and human landscapes that can be negatively impacted by land-use changes (SteffanDewenter et al. 2005; Klein et al. 2007; Giannini et al. 2015). In tropical plantations, such as coffee and cacao, proximity to natural areas and forests can boost farmers' yields by providing habitat to 
wild pollinators that pollinate farmers' crops (De Marco Jr and Coelho 2004; Greenleaf and Kremen 2006). However, despite their ecological and economic importance, pollinators are declining worldwide due to habitat loss, land-use changes, and the pervasive use of pesticides (Henry et al. 2012; Burkle et al. 2013; Oliveira et al. 2016).

In the Neotropics, orchid bees (Apidae, Euglossini) compose an important group of endemic pollinators containing nearly 250 species (Nemésio and Rasmussen 2011). They are known for their striking metallic colors and males' scent-collecting behaviors from blooming orchids and other flowers, which is allegedly used to attract females (Dressler 1982a). This behavior makes orchid bees ecologically critical as long-distance pollinators (Dressler 1982a), where individual plants are often widely spaced at low densities (Janzen 1971). Orchid bees pollinate more than 600 species of plants and are frequent visitors to hundreds more (Dressler 1982a; Ramírez et al. 2002; Rocha-Filho et al. 2012), including economically important species like Brazil nuts (Maués 2002). Orchid bees are more diverse in rainforests (Nemésio and Silveira 2007), and many species are forest-interior specialists and are sensitive to forest fragmentation (MiletPinheiro and Schlindwein 2005), in contrary to most bee groups that are usually more diverse in xeric and temperate zones (Michener 2007). Consequently, habitat loss, conversion, and degradation negatively impact orchid bee assemblages (Brosi 2009).

In the tropics, oil palm (Elaeis guineensis Jacq.) is one of the of the most important commodity plantations, as the oil has multiple uses from food to cosmetics to biofuel (Fitzherbert et al. 2008). Oil palm plantations now cover more than 14.5 million hectares worldwide, and continue to rapidly expand (Foster et al. 2011; Livingston et al. 2013). Most oil palm is in Southeast Asia, but Neotropical oil palm plantations are expanding, particularly in Brazil where oil palm production doubled from 46,000 ha in 2001 to 109,000 ha in 2009 (FAO 2013). The great majority of oil palm plantations in Brazil are located in the State of Pará, within the Belém Endemism
Center biodiversity hotspot (Gascon et al. 2001; Brandão and Schoneveld 2015). In general, conventional oil palm plantations have low conservation value due to the loss of biodiversity and simplification of habitats compared to native forests (Turner and Foster 2009; Foster et al. 2011). Further, oil palm plantation insect assemblages are typically dominated by a few abundant generalists, non-forest species, and pests (Chey 2006; Fitzherbert et al. 2008).

Some studies in the Neotropics found that orchid bee communities are sensitive to oil palm plantations and increasing isolation from forest habitat, as well as other landscape changes (Livingston et al. 2013; Powell and Powell 1987, respectively). To mitigate some of these effects, Brazilian law requires land owners to preserve forest reserves and riparian corridors (permanent protection areas or "Áreas de Preservação Permanente" in Portuguese, henceforth APPs), believing that these refuges may maintain biodiversity and corridors can connect fragmented populations (Brazilian Law n 12.651 2012; Marques and Ranieri 2012).

In this study, we examined the role of forest reserves and riparian corridors in conserving and maintaining orchid bee biodiversity in the oil palm landscape in the Brazilian State of Pará, the most important agricultural frontier for oil palm in the region (Fitzherbert et al. 2008; Butler and Laurance 2009). Since some orchid bees species are very sensitive to fragmentation and do not use the matrix environment surrounding forest fragments to disperse throughout their habitats (MiletPinheiro and Schlindwein 2005; Rosa et al. 2015), we hypothesized that orchid bee richness and abundance would be greatest in the forest reserves and lowest in the palm plantation, with the APPs containing intermediate levels of richness and abundance.

\section{MATERIALS AND METHODS}

\subsection{Study site}

The study was carried out in oil palm plantations, forest reserves, and APPs at the Agropalma Industrial Complex, near the 
municipality of Tailândia, in the southeast of the state of Pará, Brazil (Figure 1), approximately $02^{\circ} 20^{\prime}$ and $02^{\circ} 40^{\prime} \mathrm{S}$ by $48^{\circ} 30^{\prime}$ and $49^{\circ} 0^{\prime} \mathrm{W}$. Agropalma consists of 107,000 ha where 64,000 ha are preserved as forest reserves and the other 40,000 ha are conventional palm plantation (the remainder being company infrastructure). The region's climate is hot and humid, with two well-defined seasons, a dry season between June and November, when orchid bee sampling took place, and a rainy season, between December and May. Mean annual precipitation is $2451 \mathrm{~mm}$, mean temperature approximately $26{ }^{\circ} \mathrm{C}$, and relative humidity around 88.5\% (Albuquerque et al. 2010) and according to the Köppen classification is defined Af and Am (Peel et al. 2007; Alvares et al. 2014). Agropalma has eight large forest reserves in the region and forested APPs connecting them.

\subsection{Orchid bee sampling}

We sampled male orchid bees from 12 July to 28 July 2015 in three areas (sites) of each land-use type ( 3 forest reserves, 3 APPs, and 3 oil palm plantations) (Figure 1), totaling nine sampling days. This rapid survey approach is appropriate for this group of bees, and short sampling periods have been demonstrated to be nearly as effective in revealing community patterns as year-long surveys (Roubik 2004; Livingston et al. 2013). We sampled one site per day using 36 scent traps, displaced in groups of six, constituting a subsampling station, similarly to what has been previously done by Silva and De Marco Jr (2014) in Cerrado areas. The six subsampling stations within the same site were separated from one another by $500 \mathrm{~m}$ (Figure 1). The distance between palm plantation sites ranged from 5 to $10 \mathrm{~km}$; APPs

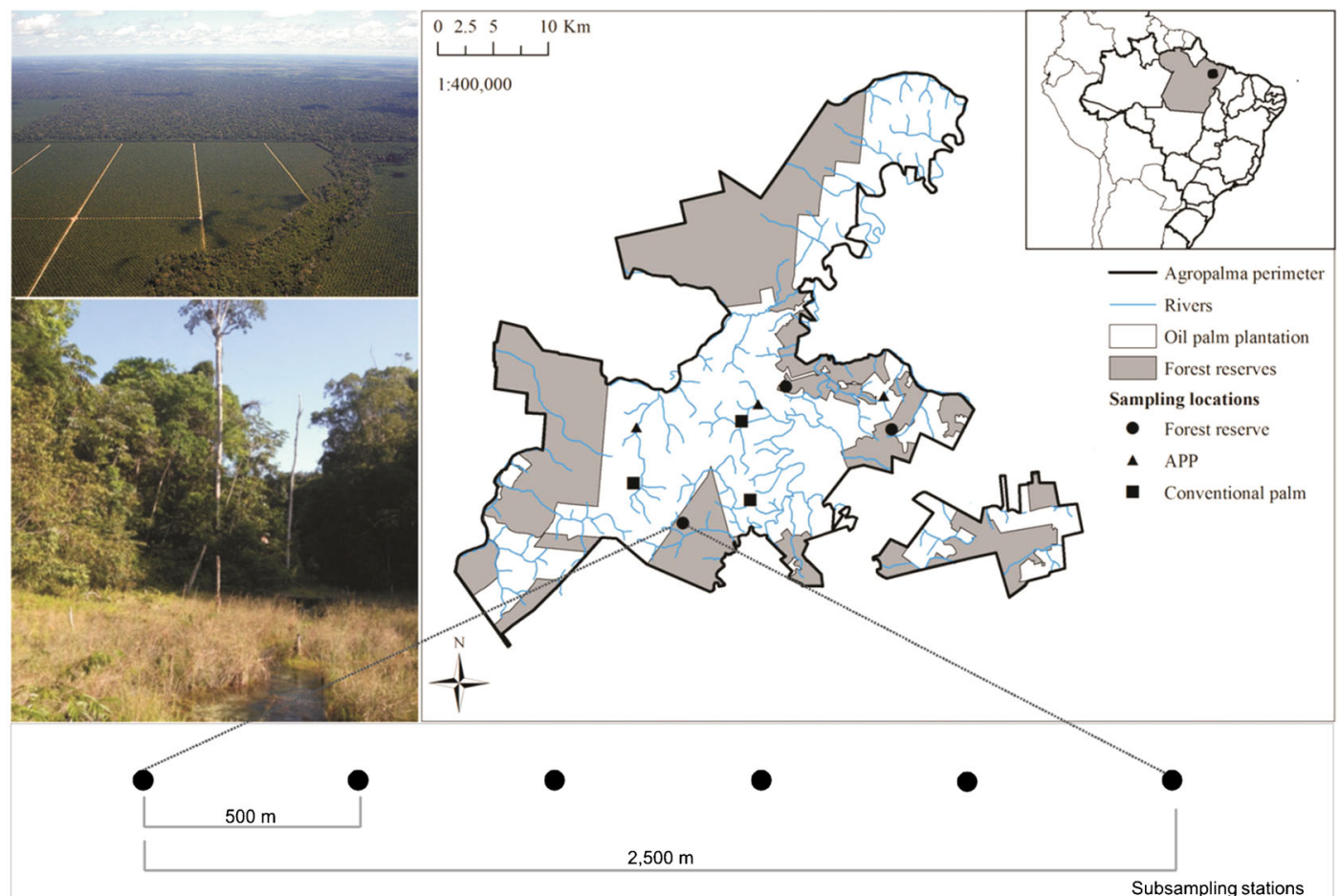

Figure 1. Map of study region near Tailândia in State of Pará, Brazil, and image of forest reserves, oil palm plantation and APPs, the dominant land uses in the region sampled. The aerial landscape photo shows the oil palm plantations, APPs ("Áreas de Preservação Permanente" or permanent protection areas), and forest reserves. The second photo shows an example of an APP with a wide, meandering stream. Points on map represent the sampled sites; each point on the map was further subsampled with 6 subsampling stations (below), each with 6 scents. (Photo credit: Agropalma Industrial Complex, upper left; C. Phifer, lower left. ) 
sites were separated from 10 to $11 \mathrm{~km}$ apart from each other, and the distance between forest sites ranged from 10 to $19 \mathrm{~km}$. Though proximity between different land-use types was often 1$2 \mathrm{~km}$ and maximum distance was approximately $20 \mathrm{~km}$. Traps were built from empty 2-L PET plastic bottles with three openings as conceived by Campos et al. (1989). At each subsampling station, six scent traps were used and each trap contained a cotton swab dipped in one of six scents: vanillin, eucalyptol, methyl cinnamate, methyl salicylate, benzyl acetate, and eugenol (Nemésio 2009).

Each land-use type site was sampled three times, with the sampling location haphazardly selected based upon existing trails and roads. All oil palm plantation sites were $\geq 2 \mathrm{~km}$ from the edge of the nearest forest reserve. For the forest sites, we walked along established trails in three large forest reserves (the smallest 4200 ha; the largest 16,700 ha, Figure S1), setting one sampling station near the edge, and then every $500 \mathrm{~m}$ along the trail, penetrating approximately $2.5 \mathrm{~km}$ into the forest reserves. Weather was warm with no rain during the sampling period and palm flowering was universally low. Traps were hung for $24 \mathrm{~h}$ (sampling effort of 2592 trap $^{-1}$ ) and then, bees were sampled, pinned, and identified to species level using taxonomic keys (Dressler 1982b; Roubik and Hanson 2004; Moure 2000; Nemésio 2009; Oliveira 2006). All bees were compared with specimens previously confirmed by Dr. André Nemésio and Dr. Márcio Oliveira, deposited in Entomology Museum of the Embrapa Amazônia Oriental and Museu Paraense Emílio Goeldi. Specimens were deposited at the Entomology Museum of the Embrapa Amazônia Oriental.

\subsection{Statistical analysis}

We calculated estimators of species richness based on first-order Jackknife using EstimateS Win9.10 software (Colwell 2013) for each site, and we compared the differences between land uses (APP, forest reserve, and palm plantations) by performing a Kruskal-Wallis test due to the non-normality nature of our data. We also performed accumulation curves of species to each land-use types, considering the random method with 9999 permutations. Differences in observed species abundance and richness among sites were compared using a one-way ANOVA, with abundance from each subsampling station log 10 transformed. We performed post hoc comparisons of significant ANOVA results by Tukey test.

To assess the distance dependence among subsampling stations on bee assemblage composition, richness, and abundance, we performed a Mantel test. The Mantel test provides a correlation coefficient value $(r)$ of comparisons between the attributes of the orchid bees and the distance of each subsampling station. Patterns of species composition were evaluated with a principal coordinates analysis (PCoA), an ordination technique where species abundances of each site (subsampling station) were $\log (x+1)$ transformed to balance values, and applied the Bray-Curtis index. To test for differences in species composition between land uses, we used a permutational multivariate analysis of variance (PERMANOVA) and to compare differences within groups and determine the effect of heterogeneity (dispersion) on significant PERMANOVA results, we performed pairwise comparisons of dispersion using Primer 6 software (PERMDISP; Anderson 2006). We also performed a nonmetric multidimensional scaling (NMDS) only as a complementary analysis, since contrary to PCoA, this ordination method does not provide explanation values of each ordination axis. We complemented our PCoA analysis with a species indicator analysis (IndVal; Dufrêne and Legendre 1997; Cáceres and Legendre 2009) to evaluate potential land-use associations for each species with the three land uses at our study site. A perfect indicator species should occur only in sampling units from a given category (specificity) and in all sampling units of that given category (fidelity).

Lastly, we evaluated the patterns of scent sampling efficiency with a Kruskal-Wallis test, and these are detailed in the supplementary material (Figure S1 and Table S2). We followed the assumptions for all statistical tests, transforming the data when necessary. We also assumed an $\alpha$ value of 0.05 in all analyses. We performed all analyses using R (2016). 


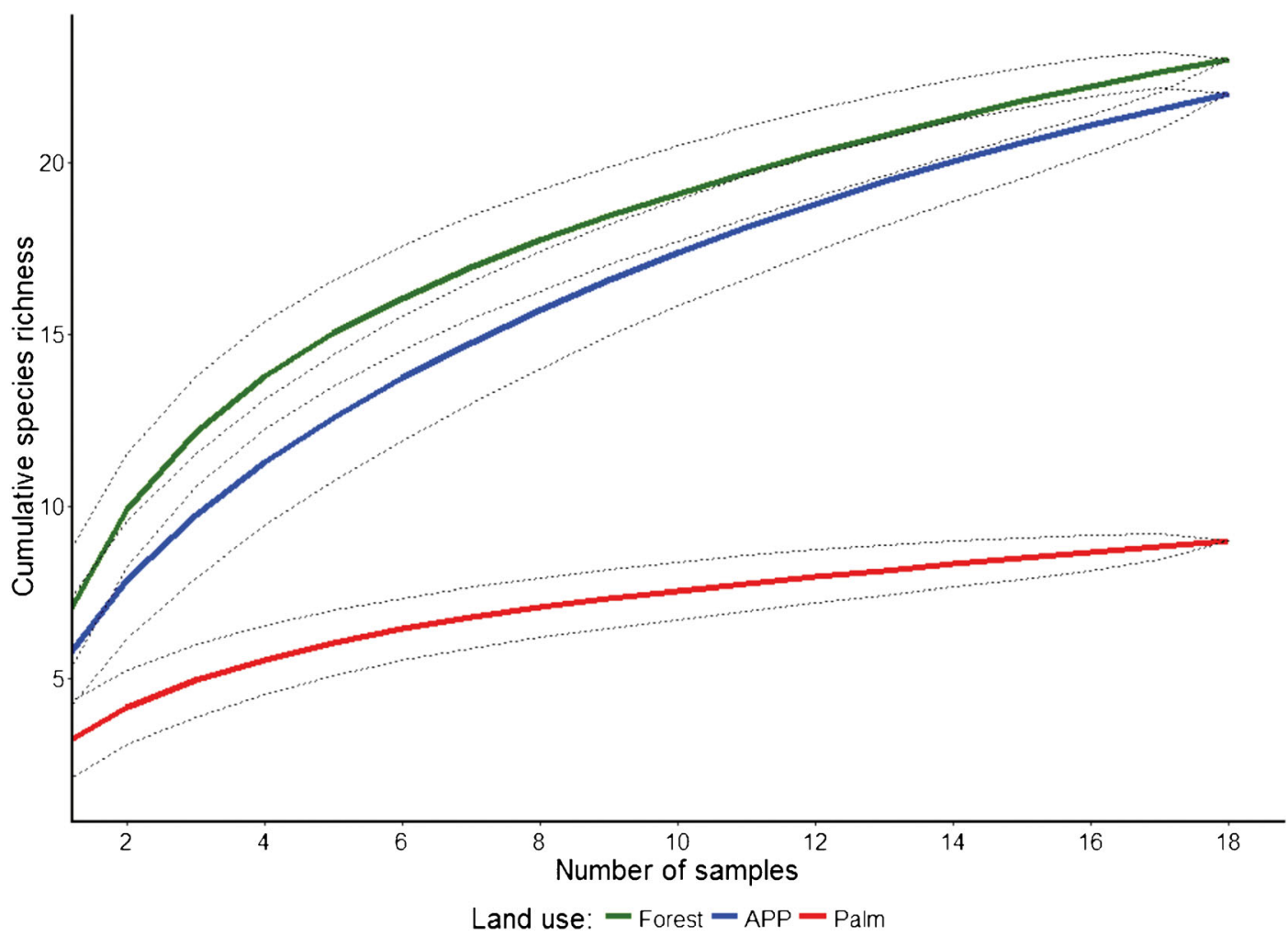

Figure 2. Cumulative curves of species (solid lines) with standard deviation (dashed lines), of orchid bees sampled at Agropalma, Tailândia municipality, State of Pará, Brazil. Land-use codes: APP "Áreas de Preservação Permanente" (permanent protection areas), Palm oil palm plantations, Forest forest reserves.

\section{RESULTS}

During our sampling period, we collected 867 male euglossine bees from 25 species belonging to four genera Eulaema (El.), Eufriesea (Ef.), Euglossa (Eg.), and Exaerete (Ex.) (Table S1), respectively, abbreviated for clarity and brevity throughout the text. In all three land uses, El. cingulata and El. meriana accounted together for $>60 \%$ of all bees collected. These two species were the dominant species in APPs and palm plantation. In contrast, Eg. chalybeata was the most abundant species in forest reserves.

Observed species richness was greatest in the forest reserves and APPs, and lowest in palm plantations $\left(F_{(2,51)}=22.577, P<0.001\right)$. Oil palm plantations had about 14 species less than forest reserves $\left(P_{\text {Tukey }}<0.001\right)$ and an amount of 13 species less when compared to APPs ( $P$ Tukey $<0.001)$. Jackknife species richness estimates in forest reserves averaged $21.61 \pm 1.34$ (mean \pm standard deviation), $17.44 \pm 4.43$ in APPs, and $7.67 \pm 0.16$ in palm plantations. Accumulation curves of species sampled in forest fragments and APPs were similar, while oil palm areas showed low values (Figure 2). Species richness estimated of forest reserves and APP areas were not different from one another $\left(H_{(2, N=9)}=7.260, P=0.036\right)$ (Figure 3). Observed abundance patterns were different from species richness patterns for each land use. Surprisingly, total abundance of orchid bees was highest in APPs (382 individuals), followed by forests (244 individuals) and palm (241 individuals) (Online Resource:Table S1), even though these differences were not significant $\left(F_{(2,51)}=1.303\right.$; $P=0.280$ ).

The composition of the orchid bee assemblage varied with land use. Both PCoA and NMDS tests revealed a clear difference between forest sites and two other land uses based on the 


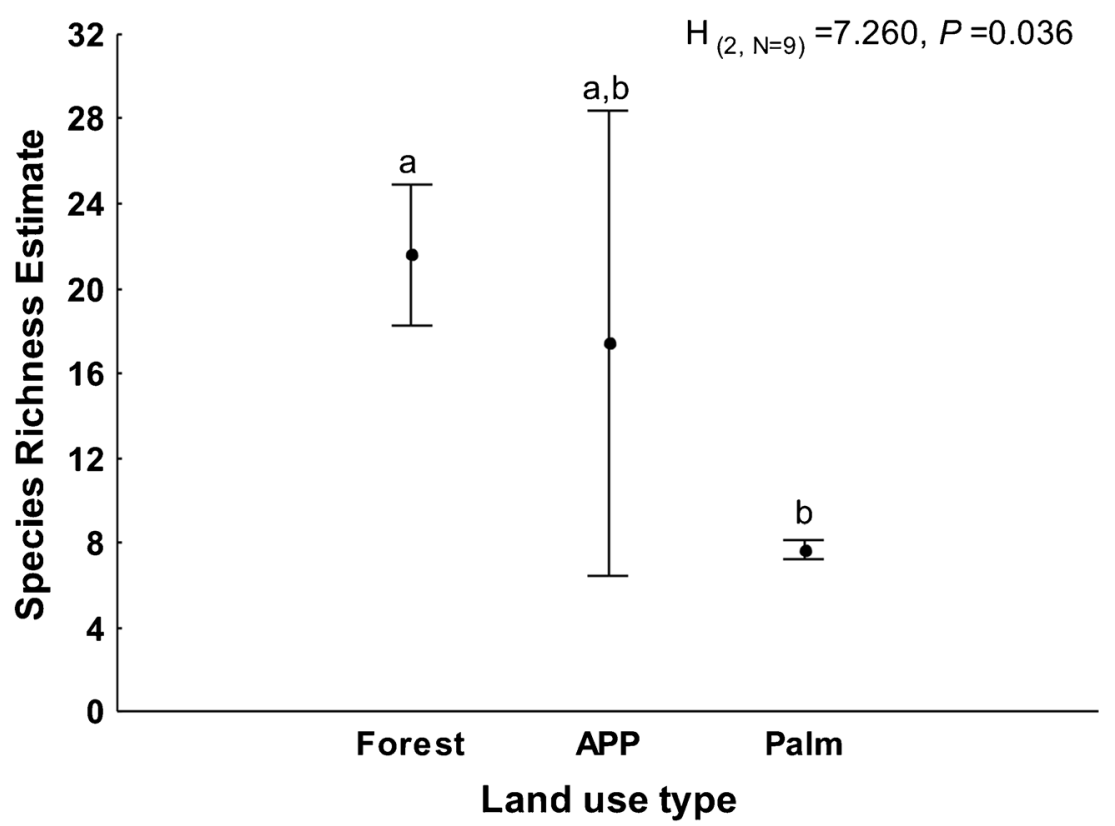

Figure 3. Comparison of the estimated species richness of euglossine bees by land use in Tailândia municipality, State of Pará, Brazil, based on first-order jackknife method. Center represents the mean and the bars represent $95 \%$ confidence intervals. Land-use codes: APP “Áreas de Preservação Permanente” (permanent protection areas), Palm oil palm plantations, Forest forest reserves.

sample composition (Figure 4a and Figure S2), with the formation of two distinct species groups within these areas (Figure 4b). Additionally, results from PERMANOVA and PERMDISP tests showed significant differences in the community composition between land uses, except a

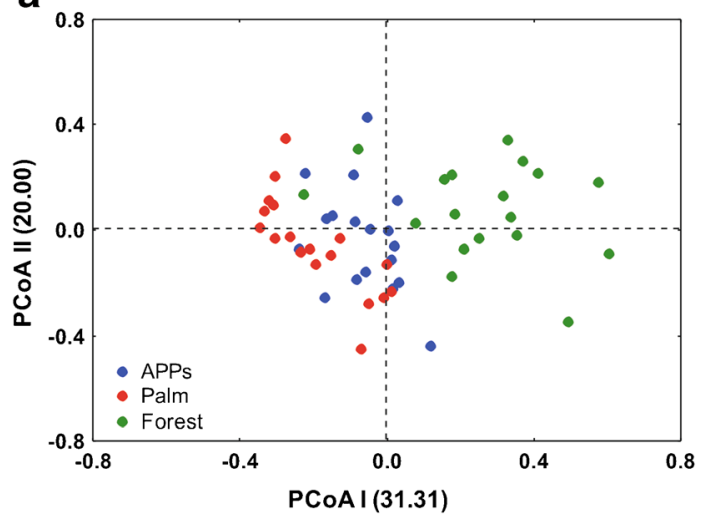

b

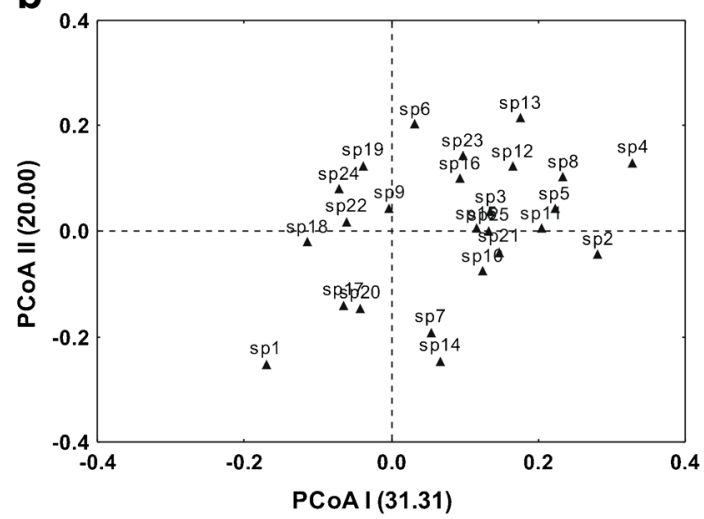

Figure 4. The principal coordinates analysis (PCoA) for data ordered by samples (a) and euglossine species (b). Landuse codes: $A P P$ "Áreas de Preservação Permanente" (permanent protection areas), Palm oil palm plantations, Forest forest reserves. Species codes: sp1, Eufriesea ornata; sp2, Euglossa amazonica; sp3, E. augaspis; sp4, E. bidentata; sp 5, E. chalybeata; sp6, E. crassipunctata; sp 7, E. ignita; $s p 8$, E. imperialis; sp9, E. intersecta; sp10, E. modestior; sp11, E. orellana; sp12, E. parvula; sp13, E. securigera; sp14, Euglossa sp.1; sp15, E. townsendi; sp16, Eulaema bombiformis; sp17, E. cingulata; sp18, E. meriana; sp19, E. mocsaryi; sp20, E. nigrita; sp21, E. polyzona; sp22, E. pseudocingulata; sp23, Exaerete frontalis; sp24, E. lepeletieri; sp25, E. smaragdina. 
between APP and palm plantation (pairwise Monte Carlo test; Table I; Figure 4). Finally, the species indicator analysis revealed five species as potential environmental bioindicators (Table II). Although Eg. bidentata, Eg. securigera, and Eg imperialis were unique to forest (Table S1), other four species were indicated as potential indicators of forest reserves (Eg. amazonica, Eg. augaspis, Eg. bidentata, and Eg. imperialis). Euglossa chalybeata was considered indicator of preserved areas (APP and Forest), despite it has been recorded in all land-use types (Table II, see also Table S1). Euglossa modestior, Eg. chalybeata, Eg. ignita, Eg. augaspis, El. bombiformis, El. cingulata, El. meriana, El. mocsaryi, and El. nigrita were found in all three land uses, and oil palm plantation was the only land use with none unique bee species (Figure 5).

We observed an effect of subsampling distances on bee abundance (Mantel $r=0.12, P=0.006$ ), observed richness (Mantel $r=0.10, P=0.015$ ) and on the variation on assemblage similarity (Mantel $r=0.11, P=0.013$ ). However, as the explanation of the geographic space on the attributes evaluated was low (Mantel $r$ values $<15 \%$ ),

Table I. Results of PERMANOVA and PERMDISP tests based on Bray-Curtis dissimilarities (25 species; 9999 permutations). The analysis did not provide values for the missing cells in the table

\begin{tabular}{llll}
\hline & df & MS & \\
\hline Source $^{\mathrm{a}}$ & & & Pseudo-F $^{*}$ \\
$\quad$ Habitat & 2 & 11,547 & $7.568^{* * * *}$ \\
$\quad$ Residuals & 51 & 1525.8 & \\
$\quad$ Total & 53 & & \\
Groups & & \\
APP vs palm & 34 & & $1.495^{\text {ns }}$ \\
APP vs forest & 34 & & $2.494^{* * * *}$ \\
Palm vs forest & 34 & & $3.632^{* * *}$ \\
\hline
\end{tabular}

$n s$ not significant

$* * * P=0.001$

a Main tests

${ }^{\mathrm{b}}$ Pairwise comparisons in subsequent analyses, we assumed that sites represented independent samples.

\section{DISCUSSION}

In this study, we found significant differences in the orchid bee assemblages present in forest reserves, APPs, and oil palm plantations. Contrary to our hypothesis, APPs did not show intermediate levels of richness and abundance of orchid bees, but had an approximately equally diverse assemblage to forest reserves. The Amazon basin contains an estimated 127 species of euglossine bees (Nemésio and Silveira 2007), and we sampled more than $20 \%$ of this species pool in a short time during the dry season when catch rates are about 38 species (Mateus et al. 2015). Overall, the community we sampled was dominated by a few species, with El. cingulata and El. meriana accounting for $>60 \%$ of the total orchid bee abundance. Nevertheless, in both forest and APP areas the species accumulation curves never plateaued, indicating that the communities are undersampled in land-use type, while sampling in the oil palm plantation seemed to have reached its peak richness.

The sampled APPs maintained high levels of euglossine bee richness and abundance, and we sampled 20 of the 23 forest species within the APPs, as well as all the species sampled within the palm plantations. This suggests that these corridors are being effectively used by the orchid bees as dispersal routes, and that they are potentially connecting all the large forest reserves. In the Atlantic rain forest, riparian strips and small forest patches were also found to be effective stepping-stones or corridors for orchid bees (Rosa et al. 2015), and APPs are believed to explain the presence of some Amazonian orchid bees within the Brazilian savanna (Silva et al. 2013; Martins et al. 2016). Similar results were also found in northeastern Brazilian humid tropical forests, where riparian forests of the São Francisco River function as biocorridors, providing refuge areas and maintaining orchid bee species (Moura and Schlindwein, 2009). Edge-dominated forests, like the APPs, in Costa Rica also supported diverse orchid bee communities (Brosi 2009). Throughout the plantation, the APPs' width varied from 50 to $250 \mathrm{~m}$, depending on the size of the stream, habitat 
Table II. Indicator values (IndVal) for euglossine species collected at different land uses in the municipality of Tailândia (State of Pará, Brazil)

\begin{tabular}{llll}
\hline Species & IndVal & $P$ & Association \\
\hline Eufriesea ornata & 0.236 & 1.000 & \\
Euglossa (Euglossa) amazonica & 0.488 & 0.035 & Forest \\
Euglossa (Euglossa) bidentata & 0.707 & 0.005 & Forest \\
Euglossa (Euglossa) modestior & 0.236 & 1.000 & \\
Euglossa (Euglossa) securigera & 0.236 & 0.345 & \\
Euglossa (Euglossa) sp. 1 & 0.333 & 0.200 & APP + forest \\
Euglossa (Euglossa) townsendi & 0.408 & 0.005 & Forest \\
Euglossa (Glossura) chalybeata & 0.808 & $\mathrm{NA}$ & Forest \\
Euglossa (Glossura) ignita & 0.707 & 0.005 & \\
Euglossa (Glossura) imperialis & 0.707 & 0.570 & \\
Euglossa (Glossura) orellana & 0.333 & 0.035 & 1.000 \\
Euglossa (Glossurela) augaspis & 0.555 & 0.060 & \\
Euglossa (Glossurella) crassipunctata & 0.236 & 0.545 & \\
Euglossa (Glossurella) parvula & 0.481 & $\mathrm{NA}$ & \\
Euglossa (Glossuropoda) intersecta & 0.333 & $\mathrm{NA}$ & \\
Eulaema (Apeulaema) cingulata & 0.933 & 0.110 & \\
Eulaema (Apeulaema) mocsaryi & 0.304 & 0.610 & \\
Eulaema (Apeulaema) nigrita & 0.512 & 0.090 & $\mathrm{NA}$ \\
Eulaema (Apeulaema) pseudocingulata & 0.298 & 0.750 & \\
Eulaema (Eulaema) bombiformis & 0.606 & 0.075 & \\
Eulaema (Eulaema) meriana & 0.892 & 1.000 & \\
Eulaema (Eulaema) polyzona & 0.289 & & \\
Exaerete frontalis & 0.527 & 0.236 & \\
Exaerete lepeletieri & 0.236 & & \\
Exaerete smaragdina & & \\
\hline & &
\end{tabular}

Ital values indicate species as potential environmental bioindicators

$N A$ non-significant values

complexity and intactness, and habitat heterogeneity, habitat features that may also explain the wider standard deviation for observed species richness in this land-use type in our study area. Other invertebrate-riparian corridor studies have shown that these forest corridors can benefit biodiversity, even if spill-over into palm matrix is low, and forest maintains greater diversity (Gray et al. 2016).

Forest fragments have been shown to be important landscape components for some euglossine bees, and it has been suggested that some of these species indeed do not leave the fragments to use the surrounding matrix (Milet-Pinheiro and Schlindwein 2005). Individual male euglossine bees routinely travel widely, especially outside of small fragments that are unlikely to provide all the life-history requirements needed for stable populations of several species of large, fast-flying bees (Tonhasca Jr et al. 2003; Brosi 2009). Additionally, orchid bees are known to fly long distances ( $\sim 30 \mathrm{~km}$ in a single day), especially the larger ones (Janzen 1971; Raw 1989; Becker et al. 1991; Wikelski et al. 2010; Pokorny et al. 2015). Thus, some Eulaema species (i.e., El. cingulata, El. mocsaryi, El. meriana, and El. bombiformis ) should be more capable of leaving forest fragments than smaller bees, as was observed for other large body size species (e.g., El. nigrita) (Raw 1989; 


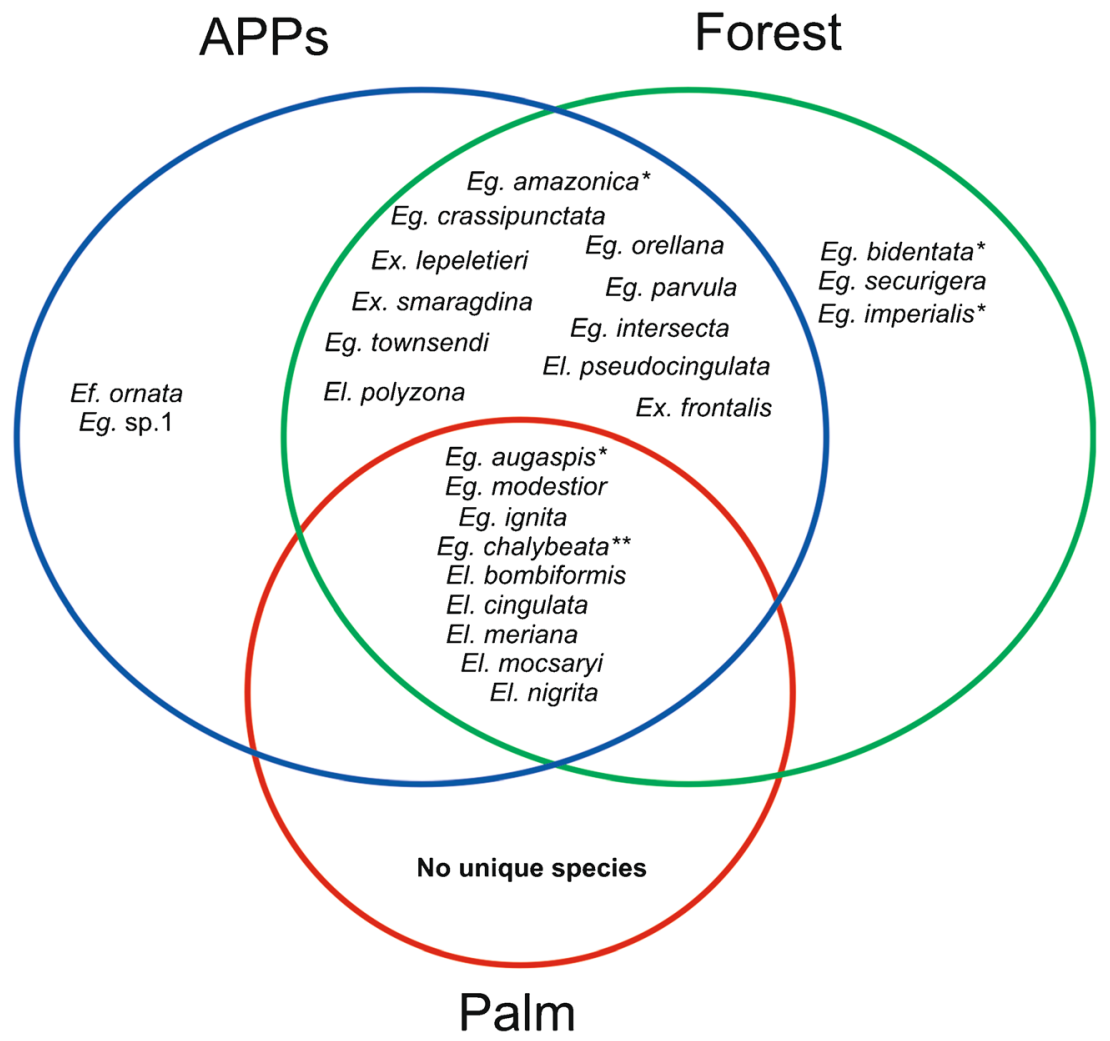

Figure 5. Venn diagram of species composition in the three land uses in Tailândia municipality, State of Pará, Brazil. Asterisks refer to species identified as indicators of forest reserves $\left({ }^{*}\right)$, indicators of preserved areas (forest reserves + APPs) (**) by the indicator analysis IndVal. No unique species was identified as being part of the oil palm plantation.

Wikelski et al. 2010; Pokorny et al. 2015). The remarkably simple orchid bee assemblages found in oil palm plantations, regarding species richness, abundance, and composition, seems to confirm the importance of forest patches to populations of these bees in the area.

Our species indicator analysis identified four euglossine bee species associated with forest reserves and one species occurred in both forested areas (forests and APPs), suggesting they are not tolerant to disturbance. Therefore, these species may be useful indicators of intact Amazonian forest orchid bee communities. Euglossa analis and Eg. sapphirina are known to be associated with forest interiors, while other species may not be affected by habitat loss (Tonhasca Jr et al. 2002; Nemésio and Silveira 2006). Contrary to what we expected, based on other studies, El. nigrita was not identified as an indicator of disturbed areas, such as the plantations we sampled. Given the ability of this species to occur in disturbed landscapes and its high flight capacity, habitat loss is not expected to cause populational decreases of this species (Silva and De Marco Jr 2014). Nonetheless, this species is expected to benefit in future scenarios of climate change and deforestation in this biome, what may facilitate its expansion to Central Amazonia (Silva et al. 2015).

Overall, our results should still be carefully interpreted. This is one of the first studies of its kind in Amazonian oil palm plantations (e.g., Shimano and Juen 2016), and we considered only three coarse land-use types. Future studies should also consider how land use affects dispersal patterns of orchid bees in the region, including finescale habitat features that may also influence bee communities, as well as temporal variations. We 
believe that previous radio-tracking studies involving bees in general (Wikelski et al. 2010; Hagen et al. 2011) may improve our understanding on how these species disperse in oil palm plantation embedded within landscapes with natural vegetation.

We also report some low-level of spatial correlation. There is no consensus on the appropriate spatial design of sampling euglossine bees, with evidence that both local and landscape features influence species (Giangarelli et al. 2015; Nemésio et al. 2016). The similarity of the orchid bee assemblage, richness, and abundance had some relatedness to the proximity of the sampled sites, but the percentage of explanation was low $(<15 \%)$. This result suggests that the differences we found are caused by the evaluated land-use types rather than sampling sites' distances. Moreover, our community results also suggest a true divergence between forest and nonforest bees. Only one study explicitly addressed the effects of spatial autocorrelation upon orchid bee diversity, with similar low levels of correlation (Brosi 2009). Considering the flight capabilities of these bees described above, ideally, all sampling points should be long-distanced from one another. Still, field logistics and site availability usually do not allow an optimal distribution of collecting sites, particularly when working in agricultural landscapes such as ours. Since we found a certain degree of space-dependence between sites, new studies that address this issue must be performed, although selecting optimal sites in crop areas, which are delimited primarily by economic reasons, is a challenging task.

Our results support the hypothesis that orchid bee species diversity would be greatest in the forest reserves and lowest in the palm, but, surprisingly, orchid bee abundance was equal in forest and APPs. Despite the worldwide negative reputation of oil palm plantations for biodiversity (e.g., Lees et al. 2015), landowners are interested in mitigating biodiversity loss. It is, therefore, critical to provide research results on the efficacy of different plantation management strategies for retaining biodiversity. Our research highlights that large-scale oil palm plantations with forest reserves and connecting APPs can be managed to protect orchid bee biodiversity.

\section{ACKNOWLEDGEMENTS}

This research was supported by the National Science Foundation Partnerships in International Research and Education (award number 124344) and the NSF International Research Experience for Undergraduates (award number DEB-1019928) for providing partial support for this project. CAPES (Coordenação de Aperfeiçoamento de Pessoal de Nível Superior) also supported this research (grant FAPAC 007/2014 for the first author). Conselho Nacional de Desenvolvimento Científico e Tecnológico (CNPq) provided LJ (process 303252/2013-8) and LFAM (process 301343/ 2012-8) with research fellowships. We are indebted to the Brazilian Embrapa Amazônia Oriental agency for its support in identifying the bee specimens from its curated reference collection. We also thank Agropalma Group for permitting this research on its property, particularly J. Martins Jr., who facilitated our research. We thank M. Cardoso and P. Cerqueira for their assistance while in the field, without which, this research would not have been possible, and Ricardo Solar (from Universidade Federal de Viçosa) and Leandro Brasil for their readiness to solve graphic doubts in R. Lastly, we thank the staff of the Programa de Pós Graduação em Zoologia at the Universidade Federal do Pará for their support and kindness and Conservation International Brazil, who helped establish this research partnership between our universities and Agropalma.

Authors' contributions TFB, CCP, JLK, FALC, MMM and DPS wrote the manuscript. TFB, CCP, JLK, CMF, NMB, and FCB collected data. TFB and CCP analyzed the data. LJ and LFAM reviewed the manuscript. CRW, DJF, JLK, LJ, LFAM and MPDS provided logistic/finnancial support.

Les zones forestières mises en réserve et les corridors riverains aident à maintenir les communautés d'abeilles à orchidée (Hymenoptera: Euglossini) dans les plantations de palmiers à huile au Brésil

Amazone / fragmentation / utilisation des terres / aires de protection permanente

Waldschutzgebiete und Uferwaldkorridore tragen zur Erhaltung von Prachtbienengemeinschaften (Hymenoptera: Euglossini) in Ölpalmenplantagen in Brasilien bei

Amazonas / Euglossini / Fragmentation / Landnutzung / Permanente Schutzgebiete 


\section{REFERENCES}

Albuquerque, M. F., Souza, E. B., Oliveira, M. C. F., Souza-Júnior, J. A. (2010) Precipitações nas mesorregiões do estado do Pará, variabilidade e tendências nas últimas décadas (1978-2008). Rev. Bras. Climatol. 6, 151-168.

Alvares, C. A., Stape, J. L., Sentelhas, P. C., Gonçalves, J. L. M., Sparovek, G. (2014) Köppen's climate classification map for Brazil. Meteorol Zeitschrift 22, 711-728.

Anderson, M. (2006) Distance-based tests for homogeneity of multivariate dispersions. Biometrics 62, 245-253.

Becker, P., Moure, J. S., Peralta, F. J. A. (1991) More about Euglossine bees in Amazonian Forest fragments. Biotropica 23, 586-591.

Brandão, F., Schoneveld, G. (2015) The state of oil palm development in the Brazilian Amazon: Trends, value chain dynamics, and business models. Working Paper 198. Bogor, Indonesia.

Brasil. (2012) Lei n 12.651 de 15 de Maio de 2012. Diário Oficial da República Federativa do Brasil, Poder Legislativo, Brasília.

Brosi, B. J. (2009) The effects of forest fragmentation on euglossine bee communities (Hymenoptera: Apidae: Euglossini). Biol. Conserv. 142, 414-423.

Burkle, L. A., Marlin, J. C., Knight, T. M. (2013) Plantpollinator interactions over 120 Years: Loss of species, co-occurrence, and function. Science 339, 1611-1615.

Butler, R. A., Laurance, W. F. (2009) Is oil palm the next emerging threat to the Amazon? Trop. Conserv. 2, 1-10.

Cáceres, M., Legendre, P. (2009) Associations between species and groups of sites: Indices and statistical inference. Ecology 90, 3566-3574.

Campos, L. A. O., Silveira, F. A., Oliveira, M. L., Abrantes, C. V. M., Morato, E. F., Melo, G. A. R. (1989) Utilização de armadilhas para a captura de machos de Euglossini (Hymenoptera, Apoidea). Rev. Bras. Zool. 6, 621-626.

Chey, V. K. (2006) Impacts of forest conversion on biodiversity as indicated by moths. Malayan Nat. J. 57, 383-418.

Colwell, R. K. (2013) EstimateS: Statistical estimation of species richness and shared species from samples. Version 9.

De Marco, Jr P., Coelho, F. M. (2004) Services performed by the ecosystem: forest remnants influence agricultural cultures' pollination and production. Biodiv. Conserv. 13, 1245-1255.

Dressler, R. L. (1982a) Biology of the orchid bees (Euglossini). Annu. Rev. Ecol. Syst. 13, 373-394.

Dressler, R. L. (1982b) New species of Euglossa (Hymenoptera: Apidae). Rev. Biol. Trop. 30, 121-150.

Dufrêne, M., Legendre, P. (1997) Species assemblages and indicator species: the need for a flexible asymmetrical approach. Ecol. Monogr. 67 : 345-366.

FAO. (2013) FAOSTAT Online Statistical Service [Internet]. https://faostat.fao.org.
Fitzherbert, E. B., Struebig, M. J., Morel, A., Danielsen, F., Bruhl, C. A., Donald, P. F., Phalan, B. (2008) How will oil palm expansion affect biodiversity? Trends Ecol. Evol. 23, 538-545.

Foster, W. A., Snaddon, J. L., Turner, E. C., Fayle, T. M., Cockerill, T. D. et al. (2011) Establishing the evidence base for maintaining biodiversity and ecosystem function in the oil palm landscapes of South East Asia. Philos. Trans. R. Soc. Lond. B Biol. Sci. 366, 3277-3291.

Gascon, C., Bierregaard Jr, R. O., Laurance, W. F., RankinDemerona, J. (2001) Deforestation and forest fragmentation in the amazon. In: Bierregaard Jr, R. O., Gascon, C., Lovejoy, T. E., Mesquita, R. (Eds). Lessons from Amazonia: the ecology and conservation of a fragmented forest. New Haven, EUA, pp. 22-30.

Giangarelli, D. C., Aguiar, W. M., Sofia, S. H. (2015) Orchid bee (Hymenoptera: Apidae: Euglossini) assemblages from three different threatened phytophysiognomies of the subtropical Brazilian Atlantic Forest. Apidologie 46, 71-83.

Giannini, T. C., Tambosi, L. R., Acosta, A. L., Jaffé, R., Saraiva, A. M., Imperatriz-Fonseca, V. L., Metzger, J. P. (2015) Safeguarding ecosystem services: A methodological framework to buffer the joint effect of habitat configuration and climate change. PLoS One 10, e0129225.

Gray, C. L., Simmons, B. I., Fayle, T. M., Mann, D. J., Slade, E. M. (2016) Are riparian forest reserves sources of invertebrate biodiversity spillover and associated ecosystem functions in oil palm landscapes? Biol. Conserv. 194, 176-183.

Greenleaf, S. S., Kremen, C. (2006) Wild bees enhance honey bees' pollination of hybrid sunflower. PNAS 103, 13890-13895.

Hagen, M., Wikelski, M., Kissling, W. D. (2011) Space use of bumblebees (Bombus spp.) revealed by radio-tracking. PLoS One 6, e19997.

Henry, M., Beguin, M., Requier, F., Rollin, O., Odoux, J. F., Aupinel, P., Aptel, J., Tchamitchian, S., Decourtye, A. (2012) A common pesticide decreases foraging success and survival in honey bees. Science 336, 348-350.

Janzen, D.H. (1971) Euglossine bees as long-distance pollinators of tropical plants. Science 171 203-205.

Klein, A. M., Vaissière, B. E., Cane, J. H., SteffanDewenter, I., Cunningham, S. A., Kremen, C., Tscharntke, T. (2007) Importance of pollinators in changing landscapes for world crops. Proc. R. Soc. B Biol. Sci. 274, 303-13.

Laurance, W. F., Sayer, J., Cassman, K. G. (2014) Agricultural expansion and its impacts on tropical nature. Trends Ecol. Evol. 29. 107-16.

Lees, A. C., Moura, N. G., Almeida, A. S., Vieira, I. C. G. (2015) Poor prospects for avian biodiversity in Amazonian oil palm. PLoS One 10, e0122432.

Livingston, G., Jha, S., Vega, A., Gilbert, L. (2013) Conservation value and permeability of neotropical oil palm landscapes for orchid bees. PLoS One 8, e78523.

Marques, E. M., Ranieri, V. E. L. (2012) Determinantes da decisão de manter áreas protegidas em terras privadas: o caso das reservas legais do estado de São Paulo. Ambiente \& Sociedade 15, 131-145. 
Martins, D. C., Albuquerque, P. M. C., Silva, F. S., Rebêlo, J. M. M. (2016) First record of Aglae caerulea (Hymenoptera, Apidae, Euglossini) in Brazilian Cerrado east of the Amazon Region, Maranhão State, Brazil. Rev Bras Biol 76, 554-556.

Mateus, S., Andrade-Silva, A. C. R., Garófalo, C. A. (2015) Diversity and temporal variation in the orchid bee community (Hymenoptera: Apidae) of a remnant of a Neotropical seasonal semi-deciduous forest. Sociobiology $62,571-577$.

Maués, M. M. (2002). Reprodutive phenology and pollination of the Brazil nut tree (Bertholletia excelsa Humb. and Bonpl. Lecythidaceae) in eastern Amazonia, in: Kevan, P. and Imperatriz-Fonseca, V. L. (Eds.), Pollination bees: The conservation link between agriculture and nature. Ministry of environment, Brasília, Distrito Federal. pp. 245-254.

MEA. (2005) Millenium Ecosystem Assessment. Ecosystems and Human Well-Being: Scenarios. Washington, DC: Island Press. http:/www.millenniumassessment. org/en/Scenarios.aspx

Michener, C. D. (2007) The Bees of the World. 2nd ed. Baltimore: The Johns Hopkins University Press.

Milet-Pinheiro, P., Schlindwein, C. (2005) Do euglossine males (Apidae, Euglossini) leave tropical rainforest to collect fragrances in sugar cane monocultures? Rev. Bras. Zool. 22, 853-858.

Moura, D. C., Schlindwein C. (2009) Mata ciliar do rio São Francisco como biocorredor para Euglossini (Hymenoptera: Apidae) de florestas tropicais úmidas. Neotrop. Entomol. 38(2), 281-284.

Moure, J. S. (2000) As espécies do gênero Eulaema Lepeletier, 1841 (Hymenoptera, Apidae, Euglossinae). Acta Biol. Parana. 29, 1-70.

Nemésio, A., Rasmussen, C. (2011) Nomenclatural issues in the orchid bees (Hymenoptera: Apidae: Euglossina) and an updated catalogue. Zootaxa $42,1-42$.

Nemésio, A., Silva, D. P., Nabout, J. C., Varela, S. (2016) Effects of climate change and habitat loss on a forestdependent bee species in a tropical fragmented landscape. Insect Conserv. Diver. 9, 149-160.

Nemésio, A., Silveira, F. A. (2007) Diversity and distribution of orchid bees (Hymenoptera : Apidae) with a revised checklist of species. Neotrop. Entomol. 36, 874-888.

Nemésio, A., Silveira, F. A. (2006) Edge effects on the orchid-bee fauna (Hymenoptera: Apidae) at a large remnant of Atlantic Rain Forest in southeastern Brazil. Neotrop. Entomol. 35, 313-323.

Nemésio, A. (2009) Orchid bees (Hymenoptera: Apidae) of the Brazilian Atlantic forest. Zootaxa 2041, 1-242.

Oliveira, M. O., Freitas, B. M., Scheper, J., Kleijn, D. (2016) Size and Sex-Dependent Shrinkage of Dutch Bees during One-and-a-Half Centuries of Land-Use Change. Plos One 11 (2), e0148983.

Oliveira, M. L. (2006) Três novas espécies de abelhas da Amazônia pertencentes ao gênero Eulaema Lepeletier, 1841 (Hymenoptera: Apidae: Euglossini). Acta Amaz. 36, 121-128.
Peel, M., Finlayson, B. L., Mcmahon, T. A. (2007) Updated world map of the Köppen-Geiger climate classification. Hydrol. Earth Syst. Sc. 11, 1633-1644.

Pokorny, T., Loose, D., Dyker, G., Quezada-Euan, J. J. G., Eltz, T. (2015) Dispersal ability of male orchid bees and direct evidence for long-range flights. Apidologie 46, 224-237.

Powell, A. H., Powell, G. V. N. (1987) Population dynamics of male Euglossine bees in Amazonian forest fragments. Biotropica 19, 176-179.

R Development Core Team. (2016) R: A language and environment for statistical computing. R Foundation for Statistical Computing. Vienna, Austria.

Ramírez, S., Dressler, R. L., Ospina, M. (2002). Abejas euglosinas (Hymenoptera: Apidae) de la región Neotropical: Listado de especies con notas sobre su biología. Biota Colomb. 3, 7-118.

Raw, A. (1989) The dispersal of Euglossine bees between isolated patches of eastern Brazilian wet forest (Hymenoptera, Apidae). Rev. Bras. Entomol. 33, 103-107.

Rocha-Filho, L. C., Krug, C., Silva, C. I., Garófalo, C. A. (2012) Floral Resources Used by Euglossini Bees (Hymenoptera: Apidae) in Coastal Ecosystems of the Atlantic Forest. Psyche (Stuttg), DOI:10.1155/2012/934951

Rosa, J. F., Ramalho, M., Monteiro, D., Silva, M. D. (2015) Permeability of matrices of agricultural crops to Euglossina bees (Hymenoptera, Apidae) in the Atlantic rain Forest. Apidologie, 46, 691-702.

Roubik, D. W., Hanson, P. E. (2004) Orchid bees of tropical America: Biology and field guide. 1st ed. San José: INBio.

Roubik, D. W. (2004) Long-term studies of solitary bees: what the orchid bees are telling us. In: Freitas, B. M., Pereira, J. O. (Eds.). Solitary Bees: Conservation, Rearing and Management for Pollination. 1st ed. Fortaleza, Imprensa Universitária, pp. 97-103.

Shimano, Y., Juen, L. (2016) How oil palm cultivation is affecting mayfly assemblages in Amazon streams. Int. J. Limnol. 52, 35-45.

Silva, D. P., Aguiar, A. J. C., Melo, G. A. R., Anjos-Silva, E. J., De Marco Jr, P. (2013) Amazonian species within the Cerrado savanna: new records and potential distribution for Aglae caerulea (Apidae: Euglossini). Apidologie 44, 673-683.

Silva, D. P., De Marco Jr, P. (2014) No evidence of habitat loss affecting the orchid bees Eulaema nigrita Lepeletier and Eufriesea auriceps Friese (Apidae: Euglossini) in the Brazilian Cerrado Savanna. Neotrop. Entomol. 43, 509-518.

Silva, D. P., Macêdo, A. C. B. A., Ascher, J. S., De Marco Jr, P. (2015) Range increase of a Neotropical orchid bee under future scenarios of climate change. J. Insect Conserv 19, 901-910.

Steffan-Dewenter, I., Potts, S. G., Packer, L. (2005) Pollinator diversity and crop pollination services are at risk. Trends Ecol. Evol. 20, 651-652; author reply 652-653.

Tomich, T. P., Brodt, S., Ferris, H., Galt, R., Horwath, W. R., et al. (2011) Agroecology: a review from a global-change perspective. Annu. Rev. Environ. Resour. 36, 193-222. 
Tonhasca, Jr A., Blackmer, J. L., Albuquerque, G. S. (2002) Abundance and diversity of Euglossine bees in the Fragmented landscape of the Brazilian Atlantic forest. Biotropica 34, 416-422.

Tonhasca Jr., A., Albuquerque, G. S., Blackmer, J. L. (2003) Dispersal of euglossine bees between fragments of the Brazilian Atlantic Forest. J. Trop. Ecol. 19, 99-102.
Turner, E. C., Foster, W. A. (2009) The impact of forest conversion to oil palm on arthropod abundance and biomass in Sabah, Malaysia. J. Trop. Ecol. 25 , 23-30.

Wikelski, M., Moxley, J., Eaton-Mordas, A., López-Uribe, M. M., Holland, R., Moskowitz, D., Roubik, D. W., Kays, R. (2010) Large-range movements of Neotropical orchid bees observed via radio telemetry. PLoS One 5, e10738. 